\title{
THE INTERNATIONAL TRADE PATTERN OF LITHUANIAN METALWORKING SECTOR
}

\author{
Gintarẻ ORLAVIČIENE் ${ }^{1}$, Mantas VILYS ${ }^{2}$ \\ Vilnius Gediminas Technical University, Vilnius, Lithuania \\ E-mails:'gintare.orlaviciene@stud.vgtu.lt;'²mantas.vilys@vgtu.lt
}

\begin{abstract}
Many international trade theories have been created until nowadays. However, not so much of real life cases were analysed in order to check their validity. The goal of this paper is to analyse Lithuanian metalworking sector in order to define whether any of international trade theories explain its international trade's pattern. In order to reach the goal scientific literature analysis was made to gain knowledge about different international trade theories. The analysis of other author's works in this field was made as well as statistical data of Lithuania's metalworking sector analyzed. The findings show that the metalworking sector follows some of the modern as well as classical international trade theories.
\end{abstract}

Keywords: international trade, trade pattern, comparative advantage, New Trade Theory, intra-industry trade, inter-industry trade, Grubel-Lloyd index, metalworking sector.

\section{Introduction}

Many international trade theories have been created in order to explain what causes countries to trade with each otherstarting from mercantilism ending to New Trade Theory for industry level analysis and Melitz theory which digs even deeper and explains, why some companies within the same industry or sector engage in international trade while others do not. This shows that international trade theories evolve during time. However, not so much of real life cases are analysed through the perspective of international trade theories - international trade is being taken for granted and not so much of attention is given nowadays to check which of international trade theories explain the cause of trade within one or another country's industry or sector. Wassily Leontief after empirical analysis in 1953 came up with the result which contradicted by that time famous Heckscher-Ohlin theory of factor endowments. This is the evidence that theories need to be revised from time to time in order to check whether they still hold.

The international trade pattern research has been a subject to several authors in Lithuania - Bernatonyte et al. (2013), Saboniene et al. (2013), Bernatonyte (2015). However, the authors have estimated only the international trade pattern of general manufacturing industries without digging deeper into those industries sectors' analysis.
The goal of this paper is to analyse Lithuanian metalworking sector in order to define whether any of international trade theories explain its international trade's pattern. To achieve this goal, the following objectives are set:

- To analyse the conception of international trade through the theoretical aspect;

- To analyze scientific literature in order to gain knowledge about the international trade theories;

- To review scientific literature of previous works about the measurement techniques of international trade pattern;

- To analyze statistical data of Lithuania's metalworking sector in terms of international trade theories in order to explain, what causes its companies to trade with foreign partners nowadays.

Research method. Scientific literature review was made to present the conception and theories of international trade and previous works of other authors about the methods to measure the trade pattern of the country, industry or sector. Statistical data from World Bank's and United Nations' databases was used to define which theories explain the metalworking sector's trade pattern.

The analysis is delimited to the manufacture of basic metals and fabricated metal products, except machinery and equipment (later - metalworking sector). It does not cover the manufacture of other metal products such as 
computers, electronic and optical products, electrical equipment, machinery and equipment, motor vehicles, trailers and semi-trailers, other vehicles and equipment as the analysis would be too broad and results may not be relevant for the whole metalworking and machine-building industry. Furthermore, the author is being interested primarily in basic metals' and fabricated metal products' sector as it is the main supplier of durable goods to the other metal industry's sectors.

\section{Conception of International Trade}

International trade is an old phenomenon, known from ancient times when the first tribes started exchanging goods with each other. Although it has some drawbacks (Lenzen et al. 2012), during the centuries international trade has evolved into economic activity which is vital for many countries, especially the smaller ones as it is one of the major sources of income for their companies. Firms that both, export and import, can be expected to benefit from the positive effects of both forms of international trade on firm survival (Wagner 2011).

If looking at the definitions of international trade, there is no universe explanation of the term - some scholars explain it in wider perspective while various dictionaries have quite narrow explanations (see Table 1). In addition, some of the sources (Cambridge Dictionaries Online 2017; Oxford University Press 2017) explain only the meaning of trade rather than international trade. However, the most common definition of international trade is activity of exchanging goods or services between countries.

Vernon (1966) stated that international trade is very complex and "imperfect" area of business. According to Krugman (1986), international trade arises because of advantages of large scale production, cumulative experience, and transitory advantages resulting from innovation. Andriusaitiene et al. (2016) elaborated that international trade exists because of the differences in production conditions - natural and material resources, specialization and others. Another important implication according to the authors is difference in labor productivity among countries. The third implication which explains the existence of international trade is the difference in customers' taste - even when countries produce similar goods, they specialize in the narrow products' lines and thus, can still trade with each other.

Although international trade is beneficial for countries, and their governmental institutions try to encourage this trade by eliminating trade barriers (for example, import tariffs) and signing free trade agreements with each other, firm participation in international trade is surprisingly rare. Researchers find that exporting and importing producers present only a tiny fraction of all the companies worldwide (Bernard et al. 2012; Melitz, Redding 2012). What is more, they find that companies engaging in exporting are usually large and the most productive ones. This is due to the fact that export is related with high fixed and marginal costs (for example, logistics costs), which is a heavy burden to small, less productive companies. However, small companies are understood differently in different parts of the world - in United States of America small company is considered having less than 500 employees while in Australia small company is the one having less than 15 employees (Cavusgil et al. 2015). Thus, some findings related to the amount of small companies' participation in the international trade may be inaccurate.

\section{Theories of International Trade}

There are several international trade theories which have evolved over time. Some of them explain the cause of international trade, other concentrate on its process. In order to understand the international trade pattern of metalworking industry of Lithuania, the theories which explain the

Table 1. Definitions of International Trade (compiled by the authors)

1 lentelè. Tarptautinès prekybos apibrèžimai (parengta autorių)

\begin{tabular}{|l|l|}
\hline \multicolumn{1}{|c|}{ Source } & \multicolumn{1}{c|}{ Definition of International Trade } \\
\hline Vernon (1966: 198) & Very complex and “imperfect" area of business. \\
\hline Bernard et al. $(2007:$ 2) & The flow of goods between countries. \\
\hline Rakauskiene, Tamosiuniene (2013: 178) & $\begin{array}{l}\text { Activity, which allows firm to use the comparative advantages of its country by } \\
\text { cultivating the division of labor and specialization. }\end{array}$ \\
\hline Cavusgil et al. (2015: 4) & $\begin{array}{l}\text { The exchange of products and services across national borders, typically through } \\
\text { exporting and importing. }\end{array}$ \\
\hline Business Dictionary (2017) & The exchange of goods or services along international borders. \\
\hline Cambridge Dictionaries Online (2017) & $\begin{array}{l}\text { The activity of buying and selling, or exchanging, goods and/or services between } \\
\text { people or countries. }\end{array}$ \\
\hline Oxford University Press (2017) & The action of buying and selling goods and services. \\
\hline
\end{tabular}


cause of international trade should be overlooked. Both, classical (mercantilist, absolute and comparative advantage, Heckscher-Ohlin and multiple-cone Heckscher-Ohlin models, Linder's overlapping product ranges theory, Product Life Cycle) and modern (New Trade Theory, Porter's Diamond of Competitive Advantage, Melitz's) trade theories are presented.

The first international trade theory was a mercantilist theory which stands for a trade surplus - country should export more than import. This theory emphasizes the importance of government actions - it should implement such policies which would encourage exports and lower the level of imports. However, this theory is outdated today, because it does not take into account that in-house production may cost much more than importing (Krugman 1997). It would be hard to find a country which would embrace mercantilist policy nowadays, especially if taking into account trade-dependent countries. Under the competitive pressure of globalization, the latter ones had to radically modify, if not completely abandon, their mercantilist policy in order to secure the benefits of international trade (Koo 2010). However, in some cases it is still possible to fruitfully employ the mercantilism in the contemporary global context (McCarthy 2013).

Another theory presented in 1776 by Adam Smith (Morgan, Katsikeas 1997) states that countries specialize in the production of goods they have absolute advantage in. According to this theory, country can improve its prosperity if it specializes in producing goods and services in which it has absolute cost advantage and imports goods and services it has absolute cost disadvantage (Smit 2010). It is claimed that such division leads to quantitative and qualitative production improvement (Schumacher 2012). More advanced theory which gave rationale for encouraging the free trade is Ricardo's theory of comparative advantage which states that country specializes in the production of goods it can produce most efficiently and exchange them to the goods that it produces less efficiently. So the key explanatory variable in Ricardo's model is relative productivity instead of absolute production costs (Costinot, Donaldson 2012).

Heckscher-Ohlin model views international differences in relative factor endowments as the fundamental cause of trade (Jones 1956; Davis 1995; Brecher et al. 2002). It states that country will produce and export goods which make intensive use of factors (for example, land, labor, capital) that are locally abundant and import goods which make intensive use of factors that are locally scarce. However, both anecdotal evidence and empirical tests tend to reject the validity of this theory (Baskaran et al. 2011). There are reasons to think that the multiple-cone
Heckscher-Ohlin (HO) model may be more relevant and plausible for the real world (Suzuki, Doi 2015; Zhang 2015).

Instead of concentrating on production advantages Linder's overlapping product ranges theory introduced in 1961 states that countries engage in trade if they have similar structures of demand and their GDP per capita are similar (Czinkota et al. 2005; Bohman, Nilsson 2007). Higher per capita income increases the quality and complexity of the product demanded and vice versa (Fernandez-Nunez, Marquez 2014; Magara 2015).

The last classical trade theory - Product Life Cycle Theory - introduced by Vernon in 1966 states that international trade is caused by technological innovation. After the products which were invented at home country reach maturity phase, both, the location of sales and the production location will change affecting the flow and direction of trade (Vernon 1979; Czinkota et al. 2005). However, this theory does not hold in all cases, because nowadays some of the companies introduce their products simultaneously at home and foreign markets.

There are few modern international trade theories. One of them is New Trade Theory which states that the firm's ability to gain economies of scale has important implications for international trade. It acknowledges imperfect competition and states that the trade between two countries can be a two-way instead of one way, because countries specialize in production of similar but narrow product lines' goods (Krugman 1998; Ethier 2014). However, there is some evidence that the world's trade is still dominated by the inter-industry trade rather than intra-industry (Emlinger, Piton 2014).

Porter's Diamond of Competitive Advantage states that countries gain advantage through four conditions: factor conditions (such as skilled labor or infrastructure, necessary to compete in a given industry), demand conditions, related and supporting industries, which are internationally competitive, and firm strategy, structure and rivalry (Aghdaie et al. 2012; Herciu 2013). These determinants create an environment in which companies are born and learn how to compete.

One of the latest international trade theories created by Melitz (2012) explains that international trade is caused by firm's productivity: it states that within the same industry some firms export and others do not - only the most productive firms choose to export their products or services while less productive firms produce only for domestic market and the least productive firms are forced to exit the market. 
Table 2. Factors Causing International Trade (compiled by the authors)

2 lentelè. Faktoriai, lemiantys tarptautinès prekybos atsiradimą (parengta autoriu)

\begin{tabular}{|l|l|l|}
\hline \multicolumn{1}{|c|}{ Type of Factor } & \multicolumn{1}{|c|}{ Factor } & \multicolumn{1}{c|}{ Theory } \\
\hline \multirow{4}{*}{ Internal } & Production costs & Absolute advantage theory \\
\cline { 2 - 3 } & Productivity & Comparative advantage theory, Melitz theory \\
\cline { 2 - 3 } & Innovation & Product Life Cycle Theory \\
\cline { 2 - 3 } & Need to reach economies of scale & New Trade Theory \\
\cline { 2 - 3 } & Firm strategy and structure & Porter's Diamond of Competitive Advantage \\
\hline \multirow{5}{*}{ External } & Political environment & Mercantilism, Porter's Diamond of Competitive Advantage \\
\cline { 2 - 3 } & Factor endowment & $\begin{array}{l}\text { Heckscher-Ohlin theory, Porter's Diamond of Competitive } \\
\text { Advantage }\end{array}$ \\
\cline { 2 - 3 } & Consumer demand & $\begin{array}{l}\text { Linder's overlapping product ranges theory, Porter's Diamond of } \\
\text { Competitive Advantage }\end{array}$ \\
\cline { 2 - 3 } & Rivalry & Porter's Diamond of Competitive Advantage \\
\hline
\end{tabular}

All the theories present the factors causing international trade, which could be divided into internal (company level) and external environment factors (see Table 2).

It seems that Porter's Diamond of Competitive Advantage covers the most of the factors causing international trade, most of them being external. In fact, this model quite well reflects today's world where all the trade decisions have to be made taking into account not only the firm's strategy and wishes but also the competitive environment, consumer demand and many other factors.

To sum up, both classical and modern trade theories were overviewed. Classical trade theories stand for inter-industry trade only - they assume that countries trade with each other by exchanging only the products or services from different industries. In most of the cases nowadays trade does not happen in such a way. That is why the most popular theories analyzed recently are New Trade Theory and Porter's Diamond of Competitive Advantage which admit imperfect competition, and analyse the issues important and relevant nowadays.

\section{Literature Review on Previous Works}

In order to measure the trade pattern of Lithuanian metalworking sector first the measurement techniques should be overviewed. The author presents the latest analysis made to measure the trade pattern. Since the author was unable to find specific works about metalworking sector, the general countries' as well as other sectors' trade analysis is presented:

- Bernatonyte et al. (2013) has estimated the pattern of Lithuanian trade with European Union (EU) from 2006 to 2012. The study has used the Relative Trade Advantage (RTA) and GrubelLloyd (GL) indexes to measure the pattern of inter-industry and intra-industry specialization between Lithuania and the EU. The analysis has covered only the main manufacturing industry's sectors such as food, raw materials, mineral fuels, chemicals, machinery and other manufactured goods without digging deeper into its subsectors. The study had revealed that Lithuania has relative trade advantage in food, drinks and tobacco; raw materials; mineral fuels, lubricants and related materials. The intra-industry trade is intensive in all the sectors except the mineral fuels, lubricants and related materials. The overlap of inter-industry and intra-industry trade patterns between food, drinks and tobacco as well as raw materials' sectors suggests that a subsector analysis should be made in order to distinguish which subsectors follow the inter-industry and which subsectors - intra-industry trade pattern. The same could be said about the other manufactured goods because they include two sectors - manufactured goods classified chiefly by material (metalworking products fall under this group) and miscellaneous manufactured articles;

- Bernatonyte (2015) has also estimated the export specialization between Lithuania and EU from 2007 to 2013. This time the author has used the Export Specialization index which is similar to Revealed Comparative Advantage (RCA) index. The results of previous and latter studies were not consistent, because the previous study has shown that the sector of other manufactured goods has followed the intra-industry trade pattern, while the latter study has revealed that the sector follows the inter-industry trade pattern;

- Srivastava and Kumar (2012) have estimated the intra-industry trade level between Greater Mekong 
Subregion countries by using GL index. Similarly Clowes (2013) has analyzed the trade between Poland and Ukraine. Ito and Okubo (2012) for analysis of trade within EU countries as well as trade between EU and China have added Vertical and Horizontal intra-industry trade indexes which take into account not only the total export and import values but also unit values of export and import;

- Emlinger and Piton (2014) presented a new database aiming at characterizing world trade flows at a disaggregated level. The new database computed has offered two measures of the share of intra-industry trade in world trade: the GL index and the Fontagné and Freudenberg index. Bano (2014) in his study in addition to GL index has added Aquino index in order to avoid bias introduced by unbalanced trade. However, his analysis has showed that both index values move in the same direction over time. The only difference is that in most of the cases Aquino index's values were higher to those of GL. As for inter-industry trade, the RCA index was used by few authors (Taneja, Wani 2014; Kumar, Ahmed 2015);

- Masali (2016) has used GL index to analyse the trade pattern between India and ASEAN countries. He has aggregated the whole industries to measure the trade, while other authors (Ambroziak 2011; Pant, Pande 2014; Wu, Shuto 2016) have adopted GL index to measure the trade between countries within specific areas such as automotive industry, pharmaceutical or food sectors.

After analyzing the techniques of measuring the international trade's pattern, it is clearly seen that the most popular techniques to identify whether the country's, its industry's or sector's trade follows classical or modern trade theories is to measure intra-industry trade by using Grubel-Lloyd index and inter-industry trade by Revealed Comparative Advantage index. Some of the authors use Fontagné and Freudenberg index as an addition to GL index, other expand the latter one into vertical and horizontal GL indexes or Aquino index in order to avoid possible biases. RCA index is sometimes replaced by RTA index. However, GL index and RCA index are the most often used indexes in the analysis of the trade pattern. GL index is useful in order to check whether the trade pattern can be explained by the New Trade Theory or not. However, in the case when the trade pattern does not follow the mentioned theory, the calculation does not indicate which classical trade theory the industry or sector follows exactly - the mercantilist, Smith's, Ricardo's, Heckscher-Ohlin's, Linder's or Product
Life Cycle's theory. This has to be interpreted by the author after making initial calculation.

\section{International Trade's Pattern of Metalworking Sector}

In order to analyze the trade pattern of metalworking sector of Lithuania the author has chosen to calculate the GL index for the main trade countries. To find out the main trading partners of Lithuania the sector's trade data was collected. The author uses the trade data of the year 2015 from United Nations database to identify the latest trade pattern and data of 2010 in order to check whether the trade pattern has changed in the long run.

In 2015 the main export countries of Lithuania's metalworking sector (United Nations 2016) were Latvia (14,5\% share from the total basic metals and fabricated metal products except machinery exports), Turkey (12\%), Norway (10,4\%), Germany (9\%), Sweden (7,9\%), Poland (7,5\%) and Netherlands (5,7\%). Lithuania was also importing basic metals and fabricated metal products from these countries. In order to check whether the trade pattern between Lithuania and its export countries holds more modern or classical trade theories the GL Index was calculated for all the export countries:

$$
G L_{i}=1-\frac{\left|X_{i}-M_{i}\right|}{X_{i}+M_{i}}
$$

where $G L_{i}$ - index of intra-industry trade for industry i, $X_{i}$ - value of export in industry i, $M_{i}$ - value of import in industry $\mathrm{i}$. The closer the $G L_{i}$ value is to 1 , the more important intra-industry trade is and vice versa - the closer the value is to 0 , the more important the inter-industry trade is.

The results (see Table 3 ) show that the trade between Latvia, Germany, Netherlands and Sweden is based on Krugman's New Trade Theory which states that countries trade with each other in similar but specialized in a narrow product lines' goods which makes them different from produced abroad. If comparing with Intra-Industry Trade Indexes of 2010, it is clearly seen that in general, the trade pattern has not changed in the long run as trade in specialized goods has happened between Lithuania and already mentioned countries, just the intensity of specialization has increased in trade with Latvia and Sweden, and decreased in trade with Germany and Netherlands.

The trade with other three countries - Turkey, Poland and Norway relies more on classical trade theories. The best explanation for the trade with Turkey and Poland would be Linder's overlapping product ranges theory, because these countries have similar GDP per capita. Lithuania's GDP per capita in 2015 was 13532 EUR (The World Bank Group 
Table 3. Intra-Industry Trade Indexes of Metalworking Sector in 2010 and 2015 (compiled by the authors) 3 lentelè. Prekybos šakos viduje indeksai 2010 ir 2015 metais metalo apdirbimo sektoriuje (parengta autoriu)

\begin{tabular}{|l|c|c|c|}
\hline \multicolumn{1}{|c|}{ Country } & Intra-Industry Trade Index 2010 & Intra-Industry Trade Index 2015 & New Trade Theory Pattern \\
\hline Germany & 0,89 & 0,62 & + \\
\hline Latvia & 0,79 & 0,89 & + \\
\hline Netherlands & 0,94 & 0,64 & + \\
\hline Norway & 0,38 & 0,26 & - \\
\hline Poland & 0,41 & 0,43 & + \\
\hline Sweden & 0,53 & 0,98 & - \\
\hline Turkey & 0,21 & 0,25 & \\
\hline
\end{tabular}

2016), Turkey's - 8729 EUR, Poland's - 12008 EUR. However, Norway is the exception in this case as its GDP per capita in 2015 was 71164 EUR - five times higher than Lithuania's. This may lead to the explanation to that of Product Life Cycle theory which states that product, when it matures, moves from highly industrialized capital-intensive country (such as Norway) to less capital-intensive lowerlabor cost country (Lithuania) which eventually becomes the exporter of product and the country which invented the product becomes the importer. This is also explained by the trade data (United Nations 2016) as from 2010 to 2015 the export value of metal products of Norway has decreased from 9,2 billion EUR to 7,5 billion EUR, while the export value of metalworking products of Lithuania has increased from 0,8 billion EUR in 2010 to 1,1 billion EUR in 2015.

To sum up, Lithuania's metalworking sector's trade pattern is mostly explained by Krugman's New Trade Theory, because two-way trade of metal products is seen between Lithuania and Latvia, Germany, Netherlands, Sweden. Trade between Poland and Turkey also happens in both ways (Lithuania exports to and imports from these countries), but they do not trade in similar, specialized products, the trade pattern is more of a classic one. It could be explained by Linder's overlapping product ranges theory as these countries are similar in GDP per capita. Finally, Norway holds the Product Life Cycle's theory, as basic metals and fabricated metal products may have reached a maturity phase, when the capital abundant, high-skilled labor Norway is decreasing its exports and lower-labor cost Lithuania is increasing the exports of metalworking industry's products.

\section{Conclusions}

The article has analyzed the concept of international trade as well as classical and modern trade theories. International trade is mostly explained as the activity of exchanging goods and services between countries. It is a complex business area caused by various - internal and external - factors.
The author has identified that classical trade theories stand for inter-industry trade. These theories assume that countries trade with each other by exchanging only the products or services from different industries. However, nowadays trade rarely happens in such a way. That is why the most popular theories analyzed recently by many scholars are New Trade Theory which stands for intra-industry trade and imperfect competition, and Porter's Diamond Model.

After analyzing the techniques of measuring the international trade's pattern, it is clearly seen that the most popular are Grubel-Lloyd and Revealed Comparative Advantage indexes' calculation. Some of the authors use Fontagné and Freudenberg index as an addition to GL index, other expand the latter one into vertical and horizontal GL indexes or Aquino index in order to avoid possible biases. RCA index is sometimes replaced by RTA index. However, GL and RCA are the most used indexes in the analysis of the trade pattern.

The analysis of statistical data has shown that the main trading partners of Lithuania for metal products were Latvia, Poland, Turkey, Germany, Norway, Netherlands and Sweden. The Lithuania's metalworking sector's trade pattern is mostly explained by Krugman's New Trade Theory, because two-way trade of metal products is seen between Lithuania and Latvia, Germany, Netherlands, Sweden. Trade between Poland and Turkey also happens in both ways, but they do not trade in similar, specialized products - the trade pattern is more of a classic one. It could be explained by Linder's overlapping product ranges theory as these countries are similar in GDP per capita. Finally, Norway holds the Product Life Cycle theory, as basic metals and fabricated metal products may have reached the maturity phase, when the capital abundant, high-skilled labor Norway is decreasing its exports and lower-labor cost Lithuania is increasing the exports of metalworking industry's products. 


\section{References}

Aghdaie, S. F. A.; Seidi, M.; Riasi, A. 2012. Identifying the barriers to Iran's saffron export by using Porter's Diamond model, International Journal of Marketing Studies 4(5): 129-138. https://doi.org/10.5539/ijms.v4n5p129

Ambroziak, L. 2011. The intra-industry trade of the Visegrad countries: the case of automotive industry [online], [cited 27 December 2016]. Available from Internet: http://www.etsg. org/ETSG2011/Papers/Ambroziak.pdf

Andriusaitiene, D.; Drejeris, R.; Jakutis, A.; Petraškevičius, V.; Stepanovas, A. 2016. Ekonomikos teorija. Vilnius: Technika. https://doi.org/10.20334/1554-S

Bano, S. 2014. Trade relations between New Zealand and China: an empirical analysis in the context of a free trade agreement, Review of Economics \& Finance 4: 75-92.

Bernard, A. B.; Jensen, J. B.; Redding, S.; Schott, P. K. 2007. Firms in international trade, Journal of Economic Perspectives 21: 105-130. https://doi.org/10.1257/jep.21.3.105

Bernard, A. B.; Jensen, J. B.; Redding, S.; Schott, P. K. 2012. The empirics of firm heterogeneity and international trade [online], [cited 01 February 2017]. Available from Internet: http://tuck-fac-cen.dartmouth.edu/images/uploads/faculty/ andrew-bernard/annurev_economics.pdf.

Bernatonyte, D.; Burksaitiene, D.; Rimiene, K. 2013. Trade specialization pattern of Lithuania, Economics and Management 18(4): 661-665.

Bernatonyte, D. 2015. Estimation of export specialization: Lithuanian case, Equilibrium. Quarterly Journal of Economics and Economic Policy 10(3): 129-138. https://doi.org/10.12775/equil.2015.028

Baskaran, T.; Blochl, F.; Bruck, T. 2011. The Heckscher-Ohlin model and the network structure of international trade, International Review of Economics and Finance 20: 135145. https://doi.org/10.1016/j.iref.2010.11.003

Bohman, H.; Nilsson, D. 2007. Market overlap and the direction of exports: a new approach of assessing the Linder hypothesis, CESIS-Electronic Working Paper Series No. 86.

Brecher, R. A.; Chen, Z.; Choudri, E. U. 2002. Absolute and comparative advantage, reconsidered: the pattern of international trade with optimal saving, Review of International Economics 10(4): 645-656. https://doi.org/10.1111/1467-9396.t01-1-00355

Business Dictionary. 2017. International Trade [online], [cited 31 January 2017]. Available from Internet: http://www.businessdictionary.com/definition/international-trade.html

Cambridge Dictionaries Online. 2017. Meaning of "trade" in the English Dictionary [online], [cited 31 January 2017]. Available from Internet: http://dictionary.cambridge.org/ dictionary/english/trade

Cavusgil, S. T.; Knight, G.; Riesenberger, R.; Rammal, H. G.; Rose, E. L. 2015. International business, the new realities. Melbourne: Pearson Australia Group Pty Ltd.

Clowes, D. 2013. Polish-Ukrainian bilateral trade relations (20062011): growth in the exchange of goods endowed with higher levels of technology [online], [cited 27 December 2016]. Available from Internet: http://irbis-nbuv.gov.ua/cgi-bin/irbis_nbuv/cgiirbis_64.exe? $\mathrm{C} 21 \mathrm{COM}=2 \& \mathrm{I} 21 \mathrm{DBN}=\mathrm{UJRN} \& \mathrm{P} 21 \mathrm{DBN}=\mathrm{UJRN}$ $\&$ IMAGE_FILE_DOWNLOAD $=1 \&$ Image_file_name $=$ PDF $/$ ape_2013_8_36.pdf
Costinot, A.; Donaldson, D. 2012. Ricardo's theory of comparative advantage: old idea, new evidence, American Economic Review: Papers \& Proceedings 2012 102(3): 453-458. https://doi.org/10.1257/aer.102.3.453

Czinkota, M. R.; Ronkainen, I. A.; Moffett, M. H. 2005. International business. Mason: Thomson South-Western.

Davis, D. R. 1995. Intra-industry trade: a Heckscher-OhlinRicardo approach, Journal of International Economics 39: 201-226. https://doi.org/10.1016/0022-1996(95)01383-3

Emlinger, C.; Piton, S. 2014. World trade flows characterization: unit values, trade types and price ranges, CEPII Working Papers, 2014-26.

Ethier, W. J. 2014. The floating world: issues in International Trade theory. Singapore: World Scientific Publishing Co. Pte. Ltd. https://doi.org/10.1142/9105

Fernandez-Nunez, T.; Marquez, M. A. 2014. The dynamics of trade composition: do trade-type interdependencies matter?, The Journal of International Trade \& Economic Development 23(5): 710-734.

https://doi.org/10.1080/09638199.2013.778897

Herciu, M. 2013. Measuring international competitiveness of Romania by using Porter's Diamond and revealed comparative advantage, Procedia Economics and Finance 6: 273-279. https://doi.org/10.1016/S2212-5671(13)00140-8

Ito, T.; Okubo, T. 2012. New aspects of intra-industry trade in EU countries [online], [cited 27 December 2016]. Available from Internet: https://ir.ide.go.jp/dspace/bitstream/2344/1166/1/ ARRIDE_Discussion_No.361_ito.pdf.

Jones, R. W. 1956. Factor proportions and the Heckscher-Ohlin theorem, The Review of Economic Studies 24(1): 1-10. https://doi.org/10.2307/2296232

Koo, M. G. 2010. Embracing free trade agreements, Korean style: from developmental mercantilism to developmental liberalism, in Bilateralism in Preferential Economic Agreements: A Special Emphasis on Bilateralism Within the EU, 8-9 October, 2010, Geneva, Switzerland.

Krugman. 1986. Strategic Trade Policy and the new international economics. Cambridge: The MIT Press.

Krugman, P. 1997. What should trade negotiators negotiate about?, Journal of Economic Literature 35: 113-120.

Krugman, P. 1998. Strategic Trade Policy and the new international economics. Cambridge: The MIT Press.

Kumar, S.; Ahmed, S. 2015. Intra-industry trade and trade complementarity: evidence from India-Sri Lanka bilateral trade, Journal of International Economics 6(2): 38-70.

Lenzen, M.; Moran, D.; Kanemoto, K.; Lobefaro, L.; Geschke, A. 2012. International trade drives biodiversity threats in developing nations, Nature 486(7401): 109-112. https://doi.org/10.1038/nature11145

Magara, D. O. 2015. The effects of East Africa community common market, protocol on cross border traders at Malaba border in Kenya: Master's thesis. School Of Business, University Of Nairobi.

Masali, A. D. 2016. Intra-industry trade in manufacturing supply chain: an empirical assessment of the India-ASEAN case, International Journal of Supply Chain Management 5(2): 27-35. 
McCarthy, J. 2013. Crude "oil mercantilism"? Chinese oil engagement in Kazakhstan, Pacific Affairs 86(2): 257-280. https://doi.org/10.5509/2013862257

Melitz, M. J.; Redding, S. J. 2012. Heterogeneous firms and trade [online], [cited 02 February 2017]. Available from Internet: http://eprints.1se.ac.uk/48928/1/dp1183.pdf

Morgan, R. E.; Katsikeas, C. S. 1997. Theories of international trade, foreign direct investment and firm internationalization: a critique, Management decision 35(1/2): 68-78. https://doi.org/10.1108/00251749710160214

Oxford University Press. 2017. Definition of "trade" in English [online], [cited 27 December 2016]. Available from Internet: https://en.oxforddictionaries.com/definition/trade.

Pant, M.; Pande, D. 2014. India-Pakistan trade: an analysis of the pharmaceutical sector [online], [cited 27 December 2016]. Available from Internet: http://icrier.org/pdf/working_paper_275.pdf

Rakauskiene, G.; Tamosiuniene, R. 2013. Šalies konkurencinguma lemiantys veiksniai, Business: Theory and Practice 14(3): 177-187.

Saboniene, A.; Masteikiene, R.; Venckuviene, V. 2013. Lithuania's export specialization according to technological classification, Mediterranean Journal of Social Sciences 4(11): 346-351. https://doi.org/10.5901/mjss.2013.v4n11p346

Schumacher, R. 2012. Adam Smith's theory of absolute advantage and the use of doxography in the history of economics, Erasmus Journal for Philosophy and Economics 5(2): 54-80.

Smit, A. J. 2010. The competitive advantage of nations: is Porter's Diamond framework a new theory that explains the international competitiveness of countries?, Southern African Business Review 14(1): 105-130.

Srivastava, P.; Kumar, U. 2012. Trade and trade facilitation in the Greater Mekong Subregion. Mandaluyong City (Philippines): Asian Development Bank.

Suzuki, K.; Doi, Y. 2015. Estimating industrial development paths for two countries based on the Multiple-Cone HeckscherOhlin model [online], [cited 16 December 2016]. Available from Internet: http://www.freit.org/WorkingPapers/Papers/ Development/FREIT1008.pdf.

Taneja, K.; Wani, N. U. H. 2014. Economic performance of Indo-China merchandise trade: an analysis of RCA and RID approaches, Journal of International Economics 5(1): 88-104.

The World Bank Group. 2016. GDP per capita [online], [cited 3 December 2016]. Available from Internet: http://data.worldbank.org/indicator/NY.GDP.PCAP.CD?view=chart
United Nations. 2016. UN Comtrade Database [online], [cited 3 December 2016]. Available from Internet: https://comtrade. un.org/data/

Vernon, R. 1966. International investment and international trade in the product cycle, The Quarterly Journal of Economics 80(2): 190-207. https://doi.org/10.2307/1880689

Vernon, R. 1979. The product cycle hypothesis in a new international environment, Oxford Bulletin of Economics \& Statistics 41(4): 255-267. https://doi.org/10.1111/j.1468-0084.1979. mp41004002.x

Wagner, J. 2011. International trade and firm performance: a survey of empirical studies since 2006 [online], [cited 31 January 2017]. Available from Internet: https://www.econstor. eu/bitstream/10419/57118/1/666700281.pdf

Wu, W.; Shuto, H. 2016. Decomposing intra-industry and net one-way trade of East Asian food market, The Japanese Journal of Rural Economics 18: 45-50. https://doi.org/10.18480/jjre.18.45

Zhang, W. B. 2015. A synthesis of the Heckscher-Ohlin and Oniki-Uzawa trade models with heterogeneous tastes, different technologies, and endogenous wealth, Scientific Annals of the "Alexandru Ioan Cuza" University of Iaşi Economic Sciences 62(3): 391-410.

\section{LIETUVOS METALO APDIRBIMO SEKTORIAUS TARPTAUTINĖS PREKYBOS MODELIS}

\section{G. Orlavičienė, M. Vilys}

Santrauka

Šiandieniame pasaulyje egzistuoja daug tarptautinès prekybos teorijų. Tačiau jų tinkamumas ir pritaikymo galimybès vienai ar kitai pramonès šakai yra retai analizuojamas. Šio darbo tikslas - išanalizuoti Lietuvos metalo apdirbimo sektorių siekiant nustatyti, ar kuri nors tarptautinès prekybos teorija paaiškina sektoriaus prekybos modeli. Norint pasiekti tikslą buvo atlikta mokslinès literatūros analizè apie tarptautinès prekybos teorijas, išanalizuoti kitu autorių darbai šia tema bei išanalizuoti statistiniai Lietuvos metalo apdirbimo sektoriaus duomenys. Tyrimo rezultatai rodo, kad metalo apdirbimo sektoriaus modelis gali būti paaiškinamas tiek klasikinèmis, tiek šiuolaikinèmis tarptautinès prekybos teorijomis.

Reikšminiai žodžiai: tarptautinès prekyba, prekybos modelis, santykinis pranašumas, naujoji prekybos teorija, prekyba šakos viduje, tarpšakinė prekyba, Grubel-Lloyd indeksas, metalo apdirbimo sektorius. 